\title{
Recalling Critical Incidents for Professional Learning
}

Guru Poudel

\begin{abstract}
Teachers have to identify their own potentials and problems in order to look their way forward. In their ongoing process of teaching and learning, teachers might have encountered many critical incidents. Recalling critical incidents has worth in restructuring the pedagogical approaches and reshaping the classroom activities because teachers develop themselves if there is challenge and responsibility. Having such a claim in mind set, this article aims to unpack the Nepalese ESL lectures stories of critical incidents and to examine the role of recalling critical incidents for their professional learning. It has been developed on the basis of the narrative of three EFL lecturers. After the thematic analysis of the data obtained through indepth interview, it has been found that EFL lectures had a story of unplanned and unexpected event of the classroom and they recalled such stories as a part of professional learning. Similarly, the reflection of critical events gave them some kind of relief in teaching practices and the events taught them a number of strategies like persuasive or threatening, co-operating, caring and sometimes being indifferent to the students.
\end{abstract}

Keywords: critical incidents, narrative inquiry, professional learning, teacher development

\section{Introduction}

A series of events, which occur during teaching/learning can motivate or dishearten the teachers. The profession of teaching is seen of different values from different perspectives. It carries the social, moral, intellectual and other values. Teaching is a battlefield for the teachers and they are the great warriors or even may be the commanders. Therefore, this is natural that they encounter a number of ups and downs in their profession. More often, these might be because of the tensions between them and the students. The events they encounter may be seen critically and they might reflect on those events to build up on their further career. This is what I am talking here as the recalling of critical incidents. Recalling of critical incidents is one of the approaches of teacher professional learning and development. Teacher professional development includes any types of the efforts or actions that they do/perform alone or in collaborations. They may include: seminar, workshop, journal writing, peer coaching, keeping portfolio, action research, and so on. Here, the focus is on unpacking 'critical incidents' (Tripp, 1993) and exploring their role as one of those strategies that the teachers can use for their growth.

Recalling and examining the role of critical incidents helps teachers know more about how they teach. It also helps them to question their own teaching practice which enables them to develop professionally. The main purpose of analyzing a critical incident is to identify good practices of teaching a teacher is adopting. It also aims to identify those practices which are not working well. It serves as a form of reflective inquiry and a sense of professional awareness. Analyzing critical incidents has a number of benefits. It helps teachers in identifying and solving the problems. However, in our context much attention has not been paid in the study of critical incidents and their roles in teachers' learning. So, the issue so far 
raised in this study discusses the role of critical incidents in teachers learning with the narratives of EFL teachers. The reason behind the selection of the very issue is that analyzing critical incidents facilitates teacher professional development to: create a greater level of self-awareness; prompt an evaluation of established routines and procedures; encourage teachers to pose critical questions about teaching; help bring beliefs to the level of awareness; create opportunities for action research; help build a community of critical practitioners; and provide a resource for teachers (Richards \& Farrell (2010). Though the analysis of critical incident is taken as a strategy of professional development in the literature, the research trends on the role of recalling those events is still nominal. Taking these insights into the considerations, this study has made attempts on recalling teachers' critical incidents and exploring their roles in relation to their professional learning.

\section{Review of Literature}

A critical incident is something which we interpret as a problem or a challenge in a certain context. It is not a routine occurrence, for example, when a student constantly arrives late in the class, when some students make noise while teachers are teaching, etc. A critical incident is often personal to an individual teacher. It can be defined as any unplanned and unanticipated event that occurs during class, outside class or during a teacher's career but is "vividly remembered" (Brookfield, 1990, p. 84). In the words of Tripp (1993), "... a critical incident is an interpretation of the significance of an event. To take something as a critical incident is a value judgment we make, and the basis of that judgment is a significance we attach to the meaning of the incident" (p. 8).

The vast majority of critical incidents, however, are not at all dramatic or obvious: they are mostly straightforward accounts of very common place events that occur in professional practice which are critical in the rather different sense that they are indicative of underlying trends, motives and structures. These incidents appear to be 'typical' rather that 'critical' at first sight, but are rendered critical through analysis (Trip, 1993).

Regarding the concept critical incident, Richards and Farrell (2010) mention that "a critical incident is an unplanned and unanticipated event that occurs during a lesson and that serves to trigger insights about some aspect of teaching and learning" (p. 13). They say that critical incident analysis refers to the documentation and analysis of teaching incidents in order to learn from them and improve practice. Such incidents compel teachers to ruminate the long-term implications they may have. This process of documentation and reflection provides opportunity for teachers "to learn more about their teaching, their learners and themselves" (Richards \& Farrell, p. 114). The definitions and ideas about critical incidents exhibit that a critical incident in teaching refers to a particular occurrence that has taken place during a lesson. Teachers make it critical because they think it important and want to utilize it for future reference. In other words, teachers sometimes face some unexpected situations which make them surprised. They take such situations to be critical because they learn something from them. Critical incidents can be both positive and negative classroom events. For examples, the study of Mena, García, \& Tillema (2011) has subsumed following positive and negative events as the reality of classroom episodes: 
- Sometimes teachers plan to engage their learners in communicative activities to promote their speaking ability. But in the classroom, they may find their students' participation more than they had expected and the better speaking practices and outcomes.

- Sometimes teachers plan to conduct group work activities. They tell their students what they are going to do; divide them into groups; assign tasks, etc. and the students start performing them.

- A teacher may check the written responses of his students. S/he only marks "excellent", "well done", "keep it up", etc. regularly on a brilliant student's notebook. S/he thinks that the student has achieved what is expected from his level.

- A teacher prepares and presents different models of lesson plans to teach different aspects (e.g. grammar, vocabulary) and skills (listening, speaking, reading, writing) and also spends a couple of weeks engaging students in practicing how to prepare lesson plans for teaching different aspects and skills.

The above examples are the incidents that happen in classroom as commonplace events. But they are critical incidents in the sense that they reveal underlying beliefs and motives within the classroom. At the first appearance, these incidents seem to be insignificant but soon they become critical when they are subject to review and analysis since they trigger a sense of weird occurrence in the particular situation. These types of incidents can be called critical incidents because they are unexpected and they prompt the teachers to stop and think about the meaning of such events so that they improve (if negative incident) their teaching in future. All incidents that take place in the classroom may not be critical. A particular event becomes critical incident depending on how it is interpreted. Sometimes teachers themselves come to interpret an incident to be critical. Sometimes they take help of their students.

\section{Identifying Critical Incidents}

Most of the critical incidents occur in the classrooms (thou may also be outside) but some critical events influence the teachers' personal and professional life. For example, a teacher may attend a workshop or a conference where $\mathrm{s} /$ he is exposed to several different new practices. S/he may interpret any of them as a valuable, critical incident which influences his/her attitude towards the existing practices. Then, $\mathrm{s} /$ he may decide to adopt this new practice in his/her classes. It is said that teachers need to develop their understanding of teaching and of themselves. According to Freeman (1996), it is necessary for teachers to put themselves at the center of telling their life stories. He says that it follows a jazz maxim: "you have to know the story in order to tell the story" (p. 89). Bartlett (1990) presents some questions to be addressed while reflecting on personal critical incidents in teaching career as: why did I become a language teacher?; Do these reasons still exist for me now?; How has my background shaped the way I teach?; What does it mean to be a language teacher?; Is the teacher I am the person I am?; What is my philosophy of language teaching?; Where did this philosophy come from?; How was this philosophy shaped?; What are my beliefs about language learning?; What critical incidents in my training to be teacher shaped me as a teacher?; Do I teach in reaction to these?; What critical incidents in my career shaped me as a teacher?; Do I teach in 
reaction to these critical incidents? Brookfield (1990) emphasizes the use of critical incident questionnaire (CIQ) in order to identify the feelings of the students regarding teaching out of which teachers can identity which incident is critical and which is not from the words of students.

\section{The Process of Analyzing Critical Incidents}

Scholars have given different frameworks to analyze critical incidents. One of the procedures to analyze critical incidents is to examine and understand the critical incident itself. Tripp (1993) has suggested that there are two stages to understanding a critical incident:

Stage 1: to describe the incident (i.e. the "what" aspect): This is the description phase. In this phase, a specific phenomenon or an issue is observed and documented.

Stage 2: to explain its meaning (i.e. the "why" aspect): In this phase, the issue is explained by the teacher in terms of its meaning or value. It is also interpreted in terms of the role it plays.

It shows that at first, an incident is described and then, it is decided why it is interpreted as a critical incident. Only those incidents which have significance in a wider context are viewed to be the critical incidents. When teachers report the critical incidents, they should follow certain steps: self-observation, describing what happened, self-awareness, and self-evaluation (Thiel, 1999):

- Self-observation: Teachers adopt different ways to observe and record their own teaching such as written narrative, audio videotaping, keeping a teaching journal, etc. The first step in analyzing critical incident is to identify all the significant and relevant events that occur in the classroom and write them in the note form.

- Describing what happened: In this step, teachers have to write a detailed description of what actually happened in their classes. This detailed description should be related to the incident which is interpreted to be critical or significant.

- Self-awareness: In this step, the teacher explains the way particular incident occurred. The teacher tries to look at the incident from every possible angle to explain why it happened.

- Self-evaluation: This step is said to be the most difficult of all. In this final step, the teacher evaluates what changes were caused due to the incident in his/her practices in teaching.

In the similar way, McCabe (2002) presents the following framework for analyzing the critical incidents from the narrative perspective:

- Orientation: This part answers the questions like: Who? When? What? and Where?

- Complication: This part outlines what happened and the problem that occurred along with any turning point in the story.

- Evaluation: This part answers the question: So what?

- Result: This part outlines and explains the resolutions to the problem.

As the part of empirical review, I studied several studies on the analysis of critical incidents, reflective practices and teachers' experiences in the literature and the review provided some insights for this study. For example, the study of Meijer (2016) presents a guided reflection procedure in the study of teachers' critical incidents aiming at supporting teachers in developing knowledge based on their practical experiences and 
linking this with research generated knowledge. He recorded the class of 21 university teachers' lesson and selected two incidents for further reflection. He investigated differences in teachers' practical knowledge as revealed in oral and written reflections. The findings suggest that the reflection procedure supports teachers to the development of practical knowledge. Similarly, the study of Procee (2015) argues that the analysis of critical incidents encourages teachers to engage in reflection of experiences, and to enhance individual's active participation. Moreover, Leijen, Valtna, Leijen, and Pedaste (2012) agree that reflection of critical incidents enables individuals to share and learn from experiences and ideas from others' perspectives, (re) interpreting and developing their own perspectives further. In the same way, the study of (Meijer, Zanting, \& Verloop, 2002) depicts that reflective discussion with experienced teachers provides insight into the thoughts or arguments that experienced teachers have concerning their teaching, which other teachers can find to be informative and useful for thinking about their own insight into the content and nature of teacher's practical knowledge. It can lead to a better understanding of the complexities of teaching and, as such, can contribute to knowledge of the relationship between educational theories and teachers' practice. Similarly Mena, García, and Tillema (2013) concluded that novice teachers are to be supported and mentored in order to raise their reflections beyond a descriptive level and to make it practical knowledge. The review shows that though various studies have been taken in teachers' reflection of critical incidents and their role in foreign contexts, I realized the need of such type of studies in relation to Nepalese EFL teachers which can bridge the existing gaps in knowledge and add a brick in research base in the area of teachers' learning.

\section{Methodology}

This study was a narrative of the three EFL teachers. The subjects were the EFL teachers who regularly attended the classes. This study tries to answer three main questions a) what are the critical incidents experienced by EFL teachers for their teaching career? b) what is the role of analyzing critical incidents in teachers' professional learning and c) how do the stories of unplanned and unexpected events help teachers for their professional development? To find answers to those questions, three experienced English language teachers teaching at master level were interviewed.

The study included the stories of three EFL teachers teaching at master level as the participants. The teachers were the temporary faculties teaching in the same place for about 6 years. They were purposively selected since the researcher was interested in knowing what different stories of unplanned and unexpected do teachers experience throughout their teaching career and what different roles of those incidents had in teachers' professional learning. The study was based on narrative inquiry as the research design and followed qualitative method. In depth interview with the participants was the major tool to elicit the data. The researcher presupposed that every teacher has his/her own story. Recalling such stories can be an important tool for developing in the profession. Teacher narratives tell "Stories of teachers' professional development within their own professional worlds" (John \& Golomombek, 2002, p.6). Similarly, by telling their stories, teachers can not only reflect on specific incidents within their teaching world, but also feel a sense of cathartic relief and it offers an outlet for tensions, feelings and frustrations about teaching (Farrel, 2013, p. 80). As a narrative inquiry, I inquired the EFL teachers about and their critical events and 
looked for deeper understanding. There is an interacting connection between meaning and its expression in language (Polkinghorne, 2008) which is a central focus in narrative inquiry. Thus, the stories of woes and foes of the teachers along with their meaning have been analyzed and interpreted in the study. Like other forms of qualitative research, narrative inquiry often involves coding field texts for themes or categories (Pinnegar \& Daynes, 2007, p.4). The field texts were taken via interview with participants. I recorded the interview and transcribed the data for the analysis. I used the seven stages of an interview investigation: thematizatizing, designing, interviewing, analyzing, verifying, and reporting (Kvale, 1996). I emphasized the data in relation to the participants' meanings on the role of recalling critical incidents in my analysis and interpretation.

\section{Results and Discussion}

The data from interview were analyzed using the framework suggested by McCabe (2002). The framework is as follows:

Orientation: This part answers the following questions: Who? When? What? Where?

Complication: It outlines what happened and the problem that occurred along with any turning point in the story.

Evaluation: This part answers the questions: So what? What this means for the participants in the story?

Result: This part outlines and explains the resolution to the problem/crisis.

(as cited in Farrel, 2013, p. 82)

Thus, the narratives collected from the teachers were analyzed developing them into these four themes. The teachers are given the codes considering the ethical factors. They are given the numbers for the confidentiality. The analysis and interpretation have been made in consistent with the objectives of the study in the subsequent discussions.

\section{Story of teacher 1}

The story of this teacher is kept here in the way it was told. It is analyzed in terms of the four sections as decided above.

Orientation. I remember one of the critical incidents during my teaching. And... this happened when was teaching in a semester of M. Ed.... I experienced gender dispute among the students during their presentations. In the classroom, the students were given some presentation tasks and during the presentation of a day, there were the girls and the boys both... And after the presentation of students, after the boys presentations... they would only ask the questions to the girls ... and ... the girls would only ask the questions to the boys... and... when they would ask the questions to each other, they would be very attacking, the responses too would be in very aggressive styles, and they would blame each other. Because of this, the classroom environment became very disruptive. But I had to manage it. This became a major critical incident of my life.

This was a war between the groups. This became a big problem. From this, what I came to understand was... a teacher needed to develop the gender harmony and the another things I felt was a teacher has to take the role mediator and has to use the persuasive strategies, convincing strategies and have to think 
of how to create a friendly environment and other things... After that event, I felt that in lower levels or school levels... the students are not matured and could not have good understanding power. And, therefore, because of that they would disturb to each other... and... in this type of advanced level class, this was not expected type of environment. And after that type of environment occurred, as a teacher, I was compelled to think of how to manage such type of differences and disputes in the class. In order to solve it, I used the persuasive strategies and I asked them to cool down ...to those students who would present themselves as aggressive ones. And, after that, I taught them about the class moralities for 5 minutes, I instructed them and I warned them that I would not like to see such type of behaviors. I further told them that, we are equal and we should have the sense of belongingness. So, this became a new learning to me that we should also seriously think over that type of situations and should suggest the students.

Complication. During the presentations, the boys and the girls would curiously watch each other so that they could find out the weaker areas of the one who would be presenting. The boys after their presentations would only ask the questions to the girls and the girls would also only ask the questions to the boys. When they would ask the questions to each other, they would be very attacking, the responses too would be in very aggressive styles, and they would blame each other. Because of this, the classroom environment became very disruptive. They would start blaming and fighting with each other resulting it into the noisy the classes.

Evaluation. This became very difficult to cool down the students. They would fight with each other but I had to manage and handle the situation. They had become the great enemies of each others. They would only speak in the satirical and attacking ways. This used to happen in most of the classes as I asked to other teachers as well. Everyone in the group, either the boys or the girls, just wanted to prove oneself as a talent one and the most powerful. I came to realize that the teachers must have good persuasive strategies for such situations.

Result. I came to know that they had developed that sort of ego boundaries in the groups. So, I became the mediator. I taught them regarding the class moralities for 5 minutes, I instructed them and I warned them that I would not like to see such type of behaviors. I instructed them saying that, inside the classroom, rather than taking it as an interaction between the girls and boys, that is to be taken as the interaction between all of us, so we should not show such types of gender biasness. I further told them that, we are equal and we should have the sense of belongingness. Thus, I used consoling and persuasive strategies to make the situation normal.

\section{Story of Teacher 2}

Orientation. One day, I was teaching 'Grammar Uses and Use'. I was teaching adjectives from the grammatical section of chapter two. Mean time one of the students suddenly stood up and started asking the questions from verbs or some such irrelevant things. Then, the debate started. I became angry at him at once. And... he started with confrontations saying that why he could not ask the questions. He started pointing at me but the other students remained totally silent. I also started discussing with him. I angrily told him, 'I didn't mean that you could not ask questions but you should ask only the relevant questions'. 
I further added, 'We also have not come here understanding the whole world'. After that, for about 5-7 minutes, we started pointing at each other and throwing the anger..... And, after that, since I could not tolerate and had become too much angry; I left the class.... But the other students came to me told to forget and leave that stuff. They said, 'Let's not take these small matters seriously; we should continue the classes regularly from tomorrow'.

.... The following day, the boy came to me much earlier than the class would begin. And, he apologized, said sorry and then.... During the incident, I felt that the student was dominating me. From that time, I asked them to ask the questions, but only could ask if they are related to the subject matter. I further told them to ask the questions related to the topic of discussions. I also started thinking differently. I accepted his excuses and since then started establishing one kind of harmony. From that time, ahh.... we continued our classes as usual regularly without any problems...

Complication. The debate between the student and me started. I became angry at him. He also showed himself as a powerful person that he would not be afraid with me. He frequently started pointing at me and I too did. He asked why they could not ask the questions but what I said was they could only ask the relevant or related questions and only from the course content discussed in that class. Finally, because of the confrontation, I could not bear and left the class. Rest of the students became very unhappy of the situation.

Evaluation. I really felt very much disturbed by his questions. I started only thinking why that boy would not ask the relevant questions and related to the subject matter. But the other students were on my side. They too felt disturbed. They wanted to continue to the classes. Still, I was feeling dominated by the student. I expected other teachers also taking that issue seriously in the class. I felt that it was the issue related to the identity of the teachers.

Result. After leaving the class, other students came to me and requested me to take the class. But I resisted that I could not do that unless he would apologize. The next day, the boy came earlier that the usual class and apologized for the event that happened the day before. He seemed to be regretting up on what he did the day before. I too understood it, and the classes went on as us

\section{Story of Teacher 3}

Orientation. One day I was teaching literature to my students. The weather of that day was not good. So, suddenly, since it was too much cloudy outside, the rooms became dark due to thick cloud. The students started lightening their mobile torches. They also started making the noises. Meanwhile, one of the students just started pointing the torch light to the front and to my face. I didn't speak anything for a while. But he did not stop, therefore, my nerves were heated and I became very much angry at the boy. Then, I told him, 'You only have the torch in your mobile? You want to show your mobile to me?' I would not have been angry had he stopped that and had my eyes not been dazzled. He also suddenly told me that he was not showing the torch to me but I was rather looking at him. Again, I became much angry and said, 'You mean I should not always look at you; Are you trying to be too much?' Other students became very much angry at him except the one sitting with him. They told me to leave such matters. After some time, I could 
read his facial expressions that he also had realized. From that day, I started concentrating less on those students because I felt upset and too bad that they could not understand me even the efforts that I had made for them. For the few next classes, in order to neglect those students and make them and myself forget that story, I just focused on my content. I would not center much on those students. I reduced the informal talks to them but continued with all others. They slowly started realizing that I was not paying attentions to them. I too came to feel that whatever they did was not intentional but something suddenly happened. Slowly, our relationships recovered and the classes went as usual.

Complication. Since my eyes were dazzled, I became too much angry. After he continuously did the same thing, I told him that he was making a show of his mobile that not only he but also others had that sort of things. He angrily looked at me and suddenly told that he was not showing the torch to me but I was rather looking at him. This made me more irritated and therefore, the confrontation continued longer. Other students also became very much angry at him except the one sitting with him. We had become good enemies for some time.

Evaluation. It made me really feel bad that the students never understand how much a teacher labors for them. At once, I also started thinking that I must not have done well for then. I was also worried that the other people may know it. Therefore, I wished it would be cooled down soon. All other students also were also not happy with him. Others were interested in the study and they wanted to continue the instruction. I felt that most were truly on my side during the event.

Result. As the other students requested me to continue, I tried too cool down myself and moved ahead in the teaching. From that day, I reduced some informal talks and continued without paying much for that matter and the student in particular. For few days, I didn't notice him and behaved as if I had forgotten that event from the next day. Slowly, the situation became as usual and that the enmity too ended.

All teachers have their own stories or incidents. Only an individual teacher knows and is much responsible in those types of events. Some events can bring the accidental changes in the teachers and the students both. That is to mean, events can have both the negative and the positive consequences. According to Theil (1999), critical incidents can be positive and/or negative events and may be identified by reflecting on a 'teaching high' or a 'teaching low'. A teaching 'high' in language class could be a sudden change in the lesson plan teachers make during class because of their perceptions of the current events (Farrel, 2013, p. 85). This has the positive impact on the changes. On the other hand, a teaching low could be a specific classroom incident that is immediately problematic or puzzling for the teacher, such as one student suddenly crying during class for no apparent reason (Farrel, ibid.)

The first research questions posed in the study was about the critical incidents experienced by EFL teachers in their teaching career. The analysis and interpretation section above has presented the details of the critical incidents of the EFL teachers. Similarly, the second question raised in the study related to the role of analyzing critical incidents in teachers' professional learning in relation to the meaning of participants' narratives. All of the three narrative cases presented above seems having significant impact on their professional growth. By sharing them, first, they got some kind of relief that everybody has it. So, it 
was not a serious accident in anyone's case. Second, they greatly have become over such types of events and the situations that they will not easily be taking those events or participating in such confrontations. Third, the events taught them a number of strategies. For example, in first case, the teacher started using a persuasive or threatening or warning or convincing strategy. In the second too, he learnt how to bring the students to the right track and how to save the face through warning or co-operating. In the third case, the teacher became aware of either caring or indifference strategy of how to behave to whom in which situations. These all incidents therefore become the great part of learning for the teachers. The teachers not only learnt, but even change their strategies.

The discussions above show that it is necessary for every teacher to be aware of what is happening in his surroundings. Doing so makes one, an understanding and a better teacher. This can be clearer from what Richards and Lockhart (1994) say, 'Research suggests that teachers who are better informed about their teaching are also better able to evaluate what aspects of their practice they may need to adjust because they are more aware of what stage they have reached in their professional development'.

Thus, sharing these type stories not only has a great value in terms of sharing and consoling each other - they also lead to the further researches. That is to mean, further surveys, experimentations; case studies and action researches can be done on the basis of that.

\section{Conclusion and Implications}

Based upon the objectives of the study, I came to the conclusion that the teachers had a good collection of critical incidents recollected in their professional learning. However, their expectations and the events were in the quite opposite directions, for instance, the first teacher, he was not expecting any sorts of gender disputes in his class that in his perspectives it was not a good thing to happen at such a higher level. Unfortunately, the students had the confrontations over their presentations because of gender related issues. Regarding the role of analyzing critical incidents in teachers' professional learning, the narratives of the teachers presented suggest a number of things. The reflection of critical events gave them some kind of relief in teaching practices and the events taught them a number of strategies like persuasive or threatening, co-operating, caring and sometimes being indifferent to the students. These strategies can have more power in building the profession of every teacher. Sharing of these kinds of events makes the teachers closer in their professions reducing the gaps in their understanding and the performance. Teachers can learn a number of aspects from the 'imposing order' (Johnson \& Golombek, 2002) that take place in the institutions.

Narrating the stories related to one's profession is not only important for the novice teachers but can be equally important to the experts too. By detailing, analyzing and interpreting important critical incidents, ESL teachers are provided with further opportunities to reflect on and consolidate their philosophical and theoretical understanding... (Farrel, 2013, p.88). That is to mean, it makes every teacher more aware, cautious, co-operative, social and rich in one's profession in one way or another.

For all this, the important thing that every teacher has to learn is the culture of learning. Therefore, it can be recommended that it is very crucial that every teacher share this type of stories either through writing or telling. Sitting together, (even forming the teachers support groups), sharing, discussing and 
finding the solutions is beneficial to everyone.

\section{References}

Bartlett, L. (1990). Teacher development through reflective teaching. In J.C. Richards \& D. Brookfield, S. D. (1990). The skillful teacher. San Francisco: Jossey Bass.

Bell, J. S. (2002) Narrative inquiry: More than just telling stories. TESOL Quarterly, 36, 207-213.

Cohen, L., Manion, L. \& Morrison, K. (2007). Research methods in education. London: Routledge.

Farrel, T. S. C. (2013). Critical incident analysis through narrative reflective practice: A case study. Iranian Journal of Language Teaching Research 1 (1), 79-89.

Farrel, T. S. C. (2013). Reflective practice for language teachers: From research to practice. London: Continuum Press.

Freeman, D. (1996). Redefining research and what teachers know. In K. Bailey and D. Nunan (Ed.). Voices from the language classroom. New York: Cambridge University Press.

Grant, C. \& Osanloo, A. (2014). Understanding, selecting, and integrating a theoretical framework in dissertation research: Creating the blueprint for your "house". Administrative Issues Journal: Education, Practice and Research, 4(2), 12-26.

Guba, E.G. \& Lincoln, Y. S. (2005). Paradigmatic controversies, contradictions, and emerging confluences. In: Denzin, N.K. and Lincoln, Y. S. (Eds.). The Sage handbook of qualitative research ( $3^{\text {rd }}$ ed.). Thousand Oaks: Sage.

Jabareen, Y. (2009). Building a conceptual framework: Philosophy, definitions, and procedure. International Journal of Qualitative Methods, 8(4), 49-62.

Johnson, K. E. \& Golombek, P. (2002). Teachers'narrative inquiry as professional development. New York: Cambridge University Press.

Kvale, S. (1996). Interviews: An introduction to qualitative research interviewing. New Delhi: Sage Publications.

Leijen, Ä., Valtna, K., Leijen, D. A. J., \& Pedaste, M. (2012). How to determine the quality of students' reflections? Studies in Higher Education, 37(2), 203-217.

Levering, B. (2002). Concept analysis as empirical method. International Journal of Qualitative Methods, 1(1), 35-48.

McCabe, A. (2002). A wellspring for development. In J. Edge (Ed.) Continuing professional development. Whitestable: IATEFL Publications.

McCabe, A. (2002). A wellspring for development. In J. Edge. (Eds.). Continuing professional development. U.K.: IATEFL Publications.

Meijer, P. C. (2016). The teacher education knowledge base: Experienced teachers' craft knowledge. In E. Baker, P. Peterson, \& B. McGaw (Eds.), International Encyclopedia of Education, 3rd Edition (vol. 7; pp. 642-649). Oxford: Elsevier.

Meijer, P. C., Zanting, A., \& Verloop, N. (2002). How can student teachers elicit experienced teachers' practical knowledge? Tools, suggestions, and significance. Journal of Teacher Education, 53(5), 406-419.

Mena, J. M., García, M. L., \& Tillema, H. H. (2013). Revealing practical knowledge through deliberate reflection in student teaching. Paper presented at the 14th Biennial Conference of the European Association for Research on Learning and Instruction (EARLI), August 30 -September 3, Exeter, United Kingdom.

Mena, J. M., García, M. L., \& Tillema, H. H. (2013). Student teacher reflective writing: what does it reveal? European Journal of Teacher Education, 36(2), 147-163.

Merriam, S. B. \& Caffarella, R. S. (1999). Learning in adulthood: A comprehensive guide. San Francisco: Jossey Bass. Miles, M. B., \& Huberman, A. M. (1994). Qualitative data analysis: An expanded source book (2 ${ }^{\text {nd }}$ ed.). Newbury Park, CA: Sage. 


\section{Journal of NELTA Gandaki (JoNG) Vol. I February 2019}

Nunan, D. (1993). Research methods in language learning. Cambridge: Cambridge University Press.

Pinnergar, S. \& Daynes, J. (2007). My writing as inquiry. Locating narrative inquiry historically. In Clandinin, D.J. (Ed.) Handbook of narrative inquiry: Mapping a methodology (pp. 1-34). Thousaands Oaks, CA: Sage.

Polkinghorne, D. (1988). Narrative knowing and the human sciences. Albany: State University of New York press.

Procee, T. (2015). EFL teacher values and identity in tertiary education in Japan. In the journal of Kanda University of international studies, 21.

Richards, J. C. \& T. S. C. Farrell. (2010). Professional development for language teachers. Cambridge: Cambridge University Press.

Stronge, J. (1997). Evaluating teaching: A guide to current thinking and best practice. California: Corwin Press.

Thiel, T. (1999). Reflections on critical incidents. Prospect, 14(1), 44-52.

Tripp, D. (1993). Critical incidents in teaching: Developing professional judgment. London: Routledge.

Mr. Guru Poudel has been teaching to the M.Ed studens in the Department of English Education, T.U and Kathmandu Shiksha Campus, Kathmandu for the last seven years. Currently, he has been contributing as an executive member of NELTA and has also been pursuing M.Phil in English language education from T.U. 